Student-Athletes Attitudes about Gender Specific Athletic Mascots

The Journal of SPORT, 2019 @ Kent State University

\title{
Attitude of Midwestern NCAA DIII Intercollegiate Athletes Towards the Usage of Gender Specific Athletic Mascots
}

\section{Tim Rickabaugh}

Defiance College 


\begin{abstract}
Although it has been over 45 years since the passage of U.S. Title IX legislation, many gender equity issues are still being addressed within both the general and sport cultures. Initially (during the 1970's) many female intercollegiate athletic programs utilized Gender Specific Athletic Mascots (GSAM's) to focus attention onto the uniqueness of their emerging programs. Since that time there has been a mass exodus of U.S. colleges and universities away from the usage of GSAM's, usually in response to internal and/or external pressure, or simply to avoid any degree of controversy related to their institutional presentation of female student groups or organizations. However, the author of this study has not uncovered any evidence of a comprehensive effort to determine the attitudes of intercollegiate athletes regarding the usage of GSAM's. This study served as an initial effort to uncover athlete attitudes related to Title IX, promoting gender equity through sport, and the usage of GSAM's. Data was collected from 284 student-athletes attending four Midwestern, small (total enrollment < 1,500) NCAA DIII colleges or universities. Analysis of the data uncovered many interesting perspectives on these issues and supported the need for a more comprehensive effort to explore the attitudes of female intercollegiate athletes before making decisions regarding how they are to be represented to the general public.
\end{abstract}

\title{
Introduction
}

Since the 1972 passage of Title IX legislation, gender equity within intercollegiate athletics has remained a primary issue of importance (and some debate) among administrators, coaches, athletes, their parents, and even spectators. During the late 1970's and early 1980's, thousands of female intercollegiate athletic programs were added within U.S. colleges and universities in order to comply with federal law and, in the spirit of the law, provide gender equity regarding athletic opportunities for college women. From their origin, many of these athletic programs chose to adopt Gender Specific Athletic Mascots (GSAM's) such as Lady Techsters, Wild Kittens, Duchesses, or Lady Vol's (Fuller \& Manning, 1987, p. 65).

During the 1970's, adopting a GASM may have been seen as enhancing the recognition of female teams through an association with their own unique gender identities. Many mascots utilized in the early 1980's seem to have taken gender differentiation to extremes. Some examples of possible overdifferentiation are (Franks, 1982, pp. 35 - 154) the Albany College of Pharmacy Pink Panthers (versus Panthers), Angelo State University Rambelles (versus 
Rams), Dickenson State Blue Chicks (versus Blue Hawks), Pittsburg State Gussies (versus Gorillas), Tarlton State TexAnns (versus Texans), and the Washington and Jefferson First Ladies (versus Presidents). Now that we are forty-five years postTitle IX, the usage of GSAM's is likely an issue worth re-addressing.

Ironically, the issue of inappropriate college athletic mascots initially arose within intercollegiate sport at the very onset of Title IX legislation. In 1972, Stanford University (Indians) and Miami University (Redskins) conducted selfexaminations of their usage of Native-American mascots in (Fuller \& Manning, 1987, p. 64). Subsequently, Stanford dropped their Indians mascot in favor of the Cardinal while Miami deferred the decision to drop their more offensive Redskins mascot until fifteen years later when they adopted the current Red Hawks mascot. The issue of culturally insensitive athletic mascots, most specifically those associated with Native Americans, still remains an issue of contention. Significant media coverage was focused upon legal and NCAA scrutiny of the University of North Dakota's usage of The Fighting Sioux and the University of Illinois's dancing mascot, Chief Illiniwek (Rickabaugh \& Rickabaugh, 2015, pp. 3-6). Barely over a decade after establishing their initial women's athletic programs in 1976, Colorado State University dropped its Lady Rams moniker (in 1987) (Eitzen \& Zinn, 1990, p. 35) choosing to simply use the Rams mascot for all teams. The female students overwhelmingly supported this change despite the Ram mascot having an inherent male identity. To those student athletes, the unity of all CSU athletes was more important than the gender identification with an athletic mascot. Despite this overwhelming support for unity between male and female intercollegiate athletic programs, as of 2015 (Figure 1.), 13.9\% of NCAA DI women's basketball programs still utilize GSAM's.

Over the past 25 years, there has been a noticeable trend of discontinuing the use of intercollegiate GSAM's. At the end of the 1980's, Eitzen \& Zinn (1990, p. 33) reported that 451 of 1,185 U.S. colleges and universities still utilized GASM's representing 38\% of all institutions. Upon conducting a 2015 search of all NCAA DI women's basketball athletic websites, the author of this study determined that 48 of 245 (13.9\%) institutions still utilize GASM's (see Figure 1.). The majority of these institutions $(\mathrm{n}=37,77 \%)$ were located in the southern United States.

The institutional athletics website search provided evidence of a trend in the discontinued usage of GASM's. Since 2000, 26 (35\%) of the 74 institutions still using GASM's have since discontinued their usage as of 2015 (see Figure 2.). During this time period college and university administrators have struggled in their reaction to internal and external pressure over their usage of GSAM's. In 2003, (Harper, D4) the University of Massachusetts was embattled in a controversy over a decision to change the athletic mascot from the Minuteman to 
a gray wolf (to be named later). After investing significant time, money, and energy into the change process, the institution reversed course and choose to maintain the use of the Minutemen as the mascot for men's teams while the women's teams remained identified as the Minutewomen. In the long run, the majority of student athletes favored a unified identity focused upon the patriots that fought to gain American independence. As recently as 2010 Lyon College (Batesville, AR) consolidated to a universal mascot (Scots) in favor of using Scots for male teams and Pipers for female teams (College Athletics and the Law, p. 2). This change was approved by a committee of student-athletes at the college.

There seems to be a consistent theme within all of these decisions, one of student athlete unity among all athletic programs. Regarding the mainstream media, this 25-year overall trend in the reduced usage of GASM's has largely gone unnoticed due to the high level of media attention to culturally-insensitive athletic mascots and the attitudes of Native American populations versus those of students athletes, administrators, alumni, and fans. Indicating the high priority given to addressing culturally insensitive athletic mascots (as compared to GSAM's), the Toronto Globe and Mail (2015 May 6) reported that Adidas was willing to donate design resources to institutions wishing to re-identify themselves via new athletic mascots not connected with Native American populations. 
Figure 1. NCAA DI Colleges \& Universities Using GASM's in 2015. $N=48$ (of $245 ; 13.9 \%$ ) of total DI members (from athletics webpages).

Geographic Region

College / University

Women's BB Mascot

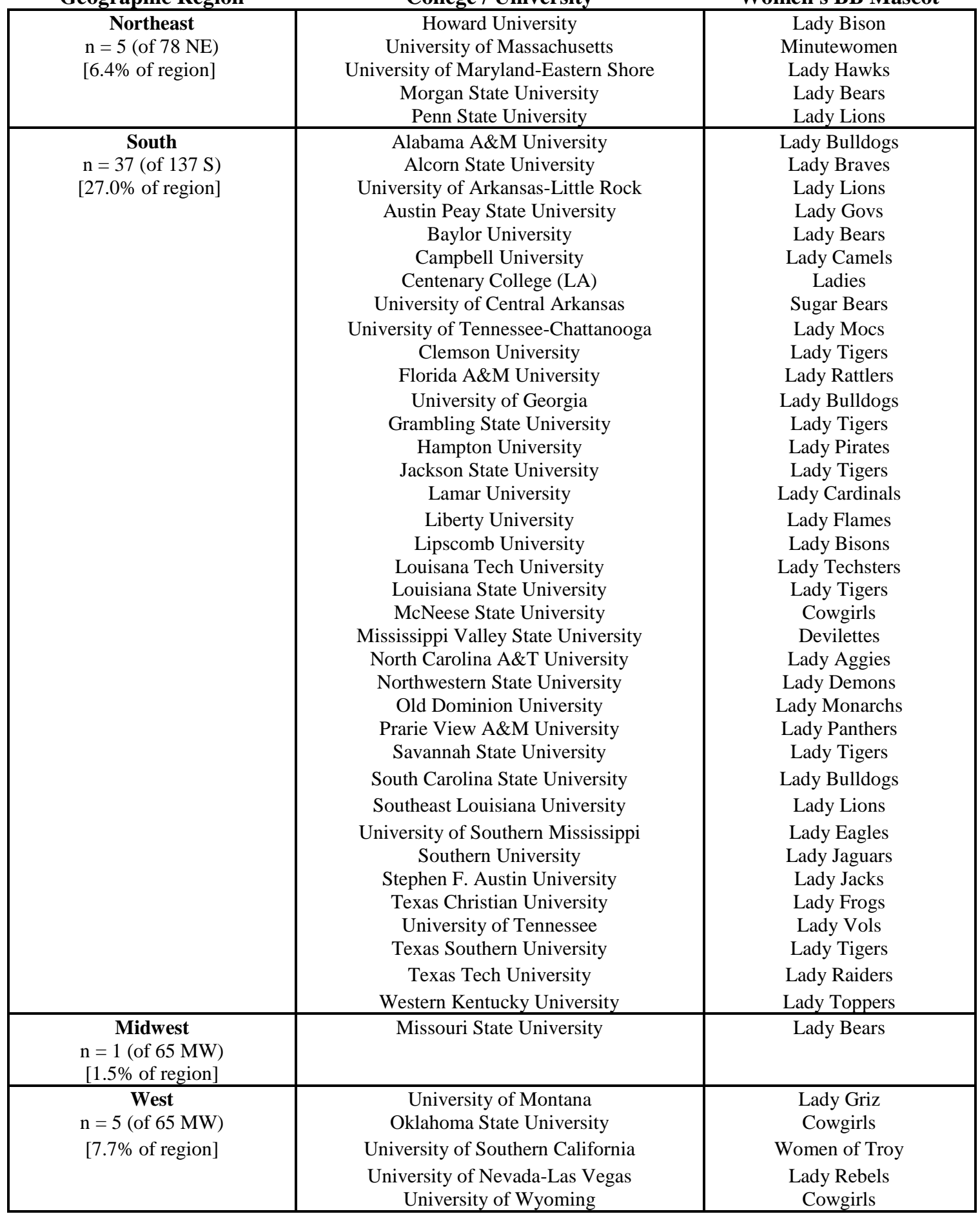


Not surprisingly, few studies have addressed the GASM issue to explore the actual attitudes of US intercollegiate athletes towards their usage. There have been numerous studies addressing gender equity issues such as the offering, funding, media coverage, and overall impact of female intercollegiate athletic programs. Regarding the portrayal of female intercollegiate athletes, it seems that our intercollegiate athletic culture is in the process of correcting an issue without first consulting those who are most directly affected. This study proposed to conduct an initial survey of current NCAA DIII intercollegiate athletes to determine their attitudes concerning the usage of GASM's.

\section{Gender Equity Issues in US Intercollegiate Athletics}

In addition to the use of GSAM's for female intercollegiate athletic teams, there are also several other important factors related to gender equity in U.S. sport. Some of the most influential of these factors includes the type of traditional and social media coverage of female programs, the types of photographs and imagery used to represent female athletes, the funding and support of female programs, and the representation of female in coaching (of both male and female teams) and other athletic leadership positions.

Regarding the media coverage of female athletics, and imagery used to represent female athletes, there are still a variety of equity issues to be addressed. Sanderson and Gramlich (2016, p. 115) reported that female athletes accounted for only $38 \%$ of sport photographs in school newspapers and that female athletes were typically shown expressing emotion (during play) as opposed to photographs of male athletes simply competing within the context of the sport. Huffman, Tuggle, \& Rosengard (2004, p.477) reported that the college newspapers they examined devoted an average of $72.7 \%$ of their coverage for male programs while college video and television programming devoted an average of $81.5 \%$ to male programs. Additionally, Senne (2016. P. 4) reported that the most common representations of female athletes within mainstream media are focused upon individual beauty, body shape, hairstyle, or other personal appearance characteristics. Hardin, Whiteside, \& Ash (2014, p. 43) surveyed NCAA DI sports information directors (SID's) and found that the profession displayed "mixed support for women's sport and Title IX" and was not generally supportive of increasing gender equity among SID's. 
Figure 2. NCAA DI Members Dropping GASM's Since 2000 $\mathrm{N}=26$ of 74 (35\%; from athletics webpages).

\begin{tabular}{|c|c|c|c|c|}
\hline $\begin{array}{c}\text { Date } \\
\text { Changed }\end{array}$ & College / University & Previous Mascot & $\begin{array}{l}\text { Current } \\
\text { Mascot }\end{array}$ & $\begin{array}{l}\text { Geographic } \\
\text { Region }\end{array}$ \\
\hline Since 2012 & $\begin{array}{c}\text { Alabama State University } \\
\text { Delaware State University } \\
\text { East Carolina University } \\
\text { East Tennessee State University } \\
\text { Eastern Kentucky University } \\
\text { Furman University } \\
\text { Georgia Southern University } \\
\text { Kennesaw State University } \\
\text { Manhattan College } \\
\text { Mississippi State University } \\
\text { Saint Peters University } \\
\text { University of North Florida } \\
\text { University of South Alabama } \\
\text { University of Tennessee- } \\
\text { Chattanooga } \\
\text { University of Texas-El Paso }\end{array}$ & $\begin{array}{l}\text { Lady Hornets } \\
\text { Lady Hornets } \\
\text { Lady Pirates } \\
\text { Lady Buccaneers } \\
\text { Lady Colonels } \\
\text { Lady Palladins } \\
\text { Lady Eagles } \\
\text { Lady Owls } \\
\text { Lady Jaspers } \\
\text { Lady Bulldogs } \\
\text { Peahens } \\
\text { Lady Ospreys } \\
\text { Lady Jaguars } \\
\text { Lady Mocs } \\
\text { Lady Miners } \\
\end{array}$ & $\begin{array}{l}\text { Hornets } \\
\text { Hornets } \\
\text { Pirates } \\
\text { Buccaneers } \\
\text { Colonels } \\
\text { Palladins } \\
\text { Eagles } \\
\text { Owls } \\
\text { Jaspers } \\
\text { Bulldogs } \\
\text { Peacocks } \\
\text { Ospreys } \\
\text { Jaguars } \\
\text { Moccasins } \\
\text { Miners } \\
\end{array}$ & $\begin{array}{l}\text { South } \\
\text { Northeast } \\
\text { South } \\
\text { South } \\
\text { South } \\
\text { South } \\
\text { South } \\
\text { South } \\
\text { Northeast } \\
\text { South } \\
\text { Northeast } \\
\text { South } \\
\text { South } \\
\text { South } \\
\text { South } \\
\end{array}$ \\
\hline 2005-2011 & $\begin{array}{c}\text { California State U. Northridge } \\
\text { Middle Tennessee State University } \\
\text { Syracuse University } \\
\text { University of Arkansas } \\
\text { University of Louisana-Layfayette } \\
\text { University of Nevada-Las Vegas } \\
\text { Western Illinois University }\end{array}$ & $\begin{array}{l}\text { Lady Matadors } \\
\text { Lady Raiders } \\
\text { Orangewomen } \\
\text { Lady Razorbacks } \\
\text { Lady Cajuns } \\
\text { Lady Rebels } \\
\text { Westerwinds } \\
\end{array}$ & $\begin{array}{l}\text { Matadors } \\
\text { Raiders } \\
\text { Orange } \\
\text { Razorbacks } \\
\text { Ragin' Cajuns } \\
\text { Rebels } \\
\text { Leathernecks } \\
\end{array}$ & $\begin{array}{l}\text { West } \\
\text { South } \\
\text { Northeast } \\
\text { South } \\
\text { South } \\
\text { West } \\
\text { Midwest }\end{array}$ \\
\hline$\frac{\text { Prior to }}{\underline{2005}}$ & $\begin{array}{c}\text { Oral Roberts University } \\
\text { New Mexico State University } \\
\text { Stony Brook University } \\
\text { University of Kentucky }\end{array}$ & $\begin{array}{l}\text { Lady Titans } \\
\text { Roadrunners } \\
\text { Lady Patriots } \\
\text { Lady Kats }\end{array}$ & $\begin{array}{l}\text { Golden } \\
\text { Eagles } \\
\text { Aggies } \\
\text { Sea Wolves } \\
\text { Wildcats }\end{array}$ & $\begin{array}{l}\text { West } \\
\text { West } \\
\text { Northeast } \\
\text { South }\end{array}$ \\
\hline NOTES: & \multicolumn{3}{|c|}{$\begin{array}{l}1 \text { = Separate mascot from men's } \\
\text { teams } \\
2=\text { The following have noted "NOT LADY" in media } \\
\text { guides: }\end{array}$} & $\begin{array}{c}\text { NE = 5 } \\
(19 \%) \\
\text { S = } 16(62 \%) \\
M W=1 \\
(4 \%)\end{array}$ \\
\hline & $\begin{array}{l}\text { Eastern Kentucky University (Colo } \\
\text { Murray State University (Racers) }\end{array}$ & & & $W=4(16 \%)$ \\
\hline
\end{tabular}

Regarding the portrayal of youth athletes in Sports Illustrated for Kids, Armentrout, Kamphoff, \& Thomae (2014, p. 47) reported that girls were more likely to be presented in non-athletic settings while boys were represented within sport competition. Additionally, the top three sports girls were represented in were basketball, non-sport roles, and soccer as compared to baseball, basketball, 
and football for boys. The outfitting of female players during intercollegiate competition can also influence factors related to gender inequality. Steinfeldt et al. (2013, p. 791) reported that the usage of revealing uniforms, typically used in women's volleyball, resulted in female athletes reporting decreased levels of body esteem as well as stating that the uniforms served as a distraction and actually impacted (negatively) on-court performance.

In the area of program funding and support, Frazier \& Caines (2015, p. 127) reported that overall athletic spending on men's programs at NCAA DI institutions exceeds that for women's programs by a $20 \%$ margin. Additionally, it was uncovered that NCAA institutions with DI football programs spent approximately 2.5 times as much to fund men's programs as compared to women's programs. Interestingly, the authors also reported that program spending at NCAA DII institutions without football had become gender-balanced by 2003 and has remained so through the publication of their findings in 2015. In U.S. high school athletics, there is also a degree of gender inequity regarding booster organizations. Anderson (2016, p. 68) reported that, of the 414 Wisconsin public high schools, only $46 \%$ required equity among booster organizations and that the majority did not require the individual organizations to provide any information regarding their sport-related fundraising activities.

Finally, the overall representation of female leaders in coaching and athletic administration positions has remained disproportionately low since the passage of Title IX in 1972. The gender-related attitudes of male leaders in sport can make a difference in the treatment, support, and presentation of female athletic teams. Fuller \& Manning (1987, p. 63) stated that "The devaluation of women is a universal component of patriarchy" and that this (patriarchal) effect is "... structurally grounded in the entire system of unequal funding and sex segregation in modern sport.” McClung \& Blinde (2002, p. 121) more recently supported the continued existence of patriarchal control in sport by stating that "The lack of representation of female coaches and athletic directors in collegiate sport serve to reinforce (and maintain) gender inequality." Senne (2016, p. 6) reported that (as of 2015) only 33\% of Women's National Basketball Association (WNBA) general manager positions were held by women, and that men comprise over $80 \%$ of the International Olympic Governing Board and U.S. National Olympic sport governing bodies.

It seems to be an established fact that despite improvements over the 25 years since the passage of Title IX, gender equity still remains an unresolved issue of concern within U.S. intercollegiate athletics. If significant levels of gender inequity currently exists in the coverage, presentation, funding, support, and leadership opportunities associated with women's athletics, then moving away from using a gender specific athletic mascot will not make the issues disappear. 
However, it is time to give NCAA athletes, male and female alike, a chance to express their attitudes regarding the usage of GSAM's. Addressing this specific gender equity issue may also direct their overall attention to broader issues of gender (and other types of) inequity that still need to be addressed and improved.

\section{Method}

In order to determine the attitudes of NCAA athletes related to gender equity and the usage of GSAM's, the author developed, piloted, and then administered a brief survey to male and female NCAA DIII athletes $(\mathrm{N}=284)$ at four small (total enrollment $<1,500$ ) Midwestern colleges (or universities) and analyzed the results. The survey was comprised of demographic items (gender, class rank, institution type, and sport type) and attitudinal items related to their overall understanding of Title IX legislation, their overall opinion of its impact on sport, their high school and college's adherence to gender equity guidelines, their high school and college's use (or disuse) of GSAM's, and their perceived mascot preference of female athletes.

Once the survey was approved by the college's Institutional Review Board, it was initially piloted utilizing 82 male and female athletes within a small, Midwestern NCAA DIII institution. Once piloted, minor adjustments were made to wording prior to completing the more comprehensive survey. At that point the finalized 11-item survey was placed into an internet-based distribution platform and selected athletic directors were contacted, provided with a statement of purpose for the study, given assurance of confidentiality of athlete responses, and provided with a link to which they could direct their student athletes.

\section{Results}

Survey respondents $(\mathrm{N}=284)$ were $53.2 \%$ females $(\mathrm{N}=151)$ and $46.8 \%$ males $(\mathrm{N}=133)$ with $76 \%$ participating in team-based sports, $16 \%$ in individualbased sports, and $8 \%$ in both types (multi-sport athletes). The class ranking of the population was rather well dispersed with $28 \%$ being freshman, $29 \%$ sophomores, $19 \%$ juniors, and $24 \%$ seniors. Specific survey questions and a qualitative summary of survey responses is presented in Figure 3.

Survey item data was also compared between genders on selected items utilizing a two-tailed, independent t-test with a critical probability level set at $\leq$ .05 . The t-test results uncovered significant gender differences for three items $(9$, $10, \& 11$ ). For item nine (reaction to: "U.S. colleges or universities should not utilize GASM's.") male respondents were more likely to agree with the statement than their female counterparts. On item ten (reaction to: "Most female athletes prefer the usage of GASM's.") male respondents were less likely to agree with the statement than their female counterparts. Finally, for item eleven (Reaction to: "It 
is important to determine if female athletes prefer the usage of GSAM's.") female respondents were more likely to agree with the statement than their male counterparts.

\section{Discussion}

Although over 45 years has passed since Title IX legislation was enacted, our survey sample still appeared to understand its historical significance $(96 \%$ expressing at least some understanding), overall positive cultural impact (74\% expressing a positive overall impact), and considers gender equity to still be a relevant issue ( $97 \%$ considering the issue at least somewhat important). Quite predictably, this population felt a strong affinity towards school-based U.S. athletics with $66 \%$ considering athletic participation to be an inherent individual right within our society.

In the area of implementation of Title IX regulations within interscholastic and intercollegiate sport, the respondents indicated that there is still need for improvement despite nearly a half-century passing since regulations were enacted. There was near consensus that gender equity in sport remains a significant cultural issue ( $97 \%$ of respondents). Despite the athletes caring deeply about the issue, they appeared to feel that public schools still have strides to make in terms of gender equity. When asked; "How well did your high school promote gender equity through sport?" $82 \%$ felt that this was either a low-level outcome or not at all a priority. On a positive note, $97 \%$ of the athletes felt that gender equity through sport was at least a low-level priority at their college or university.

This may indicate that the increased visibility of intercollegiate sport, and the oversight of the NCAA, has helped to support progressive improvements in gender equity while many public high schools have allowed this issue to be left behind. 
Student-Athletes Attitudes about Gender Specific Athletic Mascots

Figure 3. MW NCAA DIII Athlete Survey Responses $(\mathbf{N}=\mathbf{2 8 4})$

$(\mathbf{p}<\mathbf{. 0 5})=$ Significant difference between genders in item responses.

\begin{tabular}{|c|c|c|c|c|c|}
\hline Question & Response \% & & & & \\
\hline $\begin{array}{l}\text { Rate your overall level of } \\
\text { understanding of Title IX } \\
\text { legislation passed in } 1972 .\end{array}$ & $\begin{array}{l}\text { None } \\
4 \%\end{array}$ & $\begin{array}{l}\text { Some } \\
37 \%\end{array}$ & $\begin{array}{c}\text { General } \\
47 \%\end{array}$ & $\begin{array}{c}\text { Detailed } \\
12 \%\end{array}$ & \\
\hline $\begin{array}{l}\text { Rate the current overall impact } \\
\text { of Title IX on U.S. sport. }\end{array}$ & $\begin{array}{c}\text { Very Negative } \\
1 \% \\
\end{array}$ & $\begin{array}{l}\text { Somewhat } \\
\text { Negative } \\
3 \%\end{array}$ & $\begin{array}{l}\text { Little } \\
\text { Impact } \\
22 \%\end{array}$ & $\begin{array}{l}\text { Somewhat } \\
\text { Positive } \\
56 \%\end{array}$ & $\begin{array}{l}\text { Very } \\
\text { Positive } \\
18 \%\end{array}$ \\
\hline $\begin{array}{l}\text { Rate the overall importance of } \\
\text { gender equity in U.S. sport. }\end{array}$ & $\begin{array}{c}\text { Not Important } \\
3 \%\end{array}$ & $\begin{array}{c}\text { Some } \\
\text { Importance } \\
33 \%\end{array}$ & $\begin{array}{l}\text { Very } \\
\text { Important } \\
64 \%\end{array}$ & & \\
\hline $\begin{array}{l}\text { How well has your } \\
\text { college/university promoted } \\
\text { gender equity through sport? }\end{array}$ & $\begin{array}{c}\text { No Effort } \\
3 \%\end{array}$ & $\begin{array}{l}\text { Low Priority } \\
59 \%\end{array}$ & $\begin{array}{l}\text { High } \\
\text { Priority } \\
38 \%\end{array}$ & & \\
\hline $\begin{array}{l}\text { How well did your high school } \\
\text { promote gender equity through } \\
\text { sport? }\end{array}$ & $\begin{array}{c}\text { No Effort } \\
18 \%\end{array}$ & $\begin{array}{c}\text { Low Priority } \\
65 \%\end{array}$ & $\begin{array}{l}\text { High } \\
\text { Priority } \\
17 \%\end{array}$ & & \\
\hline $\begin{array}{l}\text { Is the opportunity to } \\
\text { participate in school-based } \\
\text { sport an inherent individual } \\
\text { right? }\end{array}$ & $\begin{array}{l}\text { Strongly } \\
\text { Agree } \\
22 \%\end{array}$ & $\begin{array}{l}\text { Somewhat } \\
\text { Agree } \\
44 \%\end{array}$ & $\begin{array}{l}\text { Unsure } \\
21 \%\end{array}$ & $\begin{array}{c}\text { Somewhat } \\
\text { Disagree } \\
5 \%\end{array}$ & $\begin{array}{l}\text { Strongly } \\
\text { Agree } \\
8 \%\end{array}$ \\
\hline $\begin{array}{l}\text { Does your college/university } \\
\text { utilize GASM's for female } \\
\text { athletic programs? }\end{array}$ & $\begin{array}{c}\text { Yes/For All } \\
8 \%\end{array}$ & $\begin{array}{l}\text { Yes/For } \\
\text { Some } \\
17 \%\end{array}$ & $\begin{array}{l}\text { No } \\
75 \%\end{array}$ & & \\
\hline $\begin{array}{l}\text { Did your high school utilize } \\
\text { GASM's for female athletic } \\
\text { programs? }\end{array}$ & $\begin{array}{c}\text { Yes/For All } \\
36 \%\end{array}$ & $\begin{array}{l}\text { Yes/For } \\
\text { Some } \\
24 \%\end{array}$ & $\begin{array}{c}\text { No } \\
40 \%\end{array}$ & & \\
\hline $\begin{array}{l}\text { Reaction to: "U.S. colleges (or } \\
\text { universities) should not utilize } \\
\text { GASM's." }(\mathbf{p}<\mathbf{. 0 5} ; \mathbf{M}>\mathbf{F})\end{array}$ & $\begin{array}{l}\text { Strongly } \\
\text { Agree } \\
6 \%\end{array}$ & $\begin{array}{l}\text { Somewhat } \\
\text { Agree } \\
16 \%\end{array}$ & $\begin{array}{l}\text { Unsure } \\
44 \%\end{array}$ & $\begin{array}{c}\text { Somewhat } \\
\text { Disagree } \\
19 \%\end{array}$ & $\begin{array}{l}\text { Strongly } \\
\text { Agree } \\
15 \%\end{array}$ \\
\hline $\begin{array}{l}\text { Reaction to: "Most female } \\
\text { athletes prefer the usage of } \\
\text { GSAM's." }(\mathbf{p}<\mathbf{. 0 5} ; \mathbf{M}>\mathbf{F})\end{array}$ & $\begin{array}{l}\text { Strongly } \\
\text { Agree } \\
1 \%\end{array}$ & $\begin{array}{l}\text { Somewhat } \\
\text { Agree } \\
13 \%\end{array}$ & $\begin{array}{l}\text { Unsure } \\
46 \%\end{array}$ & $\begin{array}{c}\text { Somewhat } \\
\text { Disagree } \\
24 \%\end{array}$ & $\begin{array}{l}\text { Strongly } \\
\text { Agree } \\
16 \%\end{array}$ \\
\hline $\begin{array}{l}\text { Reaction to: "It is important to } \\
\text { determine if female athletes } \\
\text { prefer the usage of GSAM's." } \\
\text { (p<.05; } \mathbf{M}<\mathbf{F})\end{array}$ & $\begin{array}{c}\text { Strongly } \\
\text { Agree } \\
15 \% \\
\end{array}$ & $\begin{array}{l}\text { Somewhat } \\
\text { Agree } \\
27 \% \\
\end{array}$ & $\begin{array}{c}\text { Unsure } \\
43 \%\end{array}$ & $\begin{array}{c}\text { Somewhat } \\
\text { Disagree } \\
9 \% \\
\end{array}$ & $\begin{array}{c}\text { Strongly } \\
\text { Agree } \\
6 \% \\
\end{array}$ \\
\hline
\end{tabular}


For the issue of Gender Specific Athletic Mascots (GASM's), attitudes appear to vary greatly within the population we surveyed. Their responses reflected the recent trend of dropping intercollegiate GASM's with 76\% reporting that their college or university used identical mascots for both male and female athletic programs. However, they also reported that $60 \%$ of their high schools still utilize GASM's for at least some of the female athletic teams. Regarding their individual opinions on the usage of GASM's, there was no general consensus regarding either support of, or opposition to, their usage. While $22 \%$ of respondents felt that GASM's should not be utilized for college athletic programs, $33 \%$ were opposed to discontinuing their usage. Interestingly, male respondents were more likely $(\mathrm{p}<.05)$ to oppose GASM usage that female respondents. Regarding the perceived (or actual) preference of female athletes, $40 \%$ of respondents felt that they (female athletes) were opposed to the usage of GSAM's. Once again, male respondents were more likely to express perceived opposition to GASM's $(\mathrm{p}<.05)$ than actual preference expressed by the female athletes surveyed.

Most important to be considered is; "Should the opinions of female athletes be accurately determined prior to an across the board exodus from the usage of GSAM's for female intercollegiate athletic programs?" Because we are institutions of higher learning, supposedly making sound decisions based upon research, one would think that asking the actual participants being directly impacted would be the first step towards either continuing or dropping the usage of GSAM's. From my research into this issue, this does not seem to be the usual scenario. Most likely, it appears that high-level administrators, which are disproportionally white males, make and implement these changes in response to internal and external pressures, or simply to avoid any degree of controversy regarding their depiction of female student groups within their overall institutional image. Ironically, the same disproportionally white male administrators that initially supported and implemented GSAM's, some as comical and/or degrading as Sugar Bears, Wild Kittens, and Pea Hens, are now dropping gender specific mascots before initially asking female athletes so that an informed decision can be made. Our survey seemed to confirm this trend with male respondents being less concerned $(\mathrm{p}<.05)$ than their female counterparts in reacting to the statement; "It is important to determine if female intercollegiate athletes prefer (or oppose) the usage of gender specific athletic mascots. 


\section{Conclusion}

Despite the fact that most current intercollegiate athletes were born more than 20 years after Title IX legislation was enacted, they (male and female alike) still recognize the importance of gender equity and feel that U.S. sport culture should promote gender equity. While intercollegiate programs seem to have made this outcome and institutional priority, public high schools may be lagging behind in their emphasis of gender equity through sport.

Regarding the usage of gender specific athletic mascots (GSAM's) for female athletic programs, this trend is still rather common within our public high schools while U.S. colleges and universities are generally dropping them in favor of the identical presentation of all athletic programs. While this movement away from the usage of intercollegiate GSAM's may seem to be a noble step towards promoting gender equity, it does not usually appear to be an informed process regarding the preferences of the female athletes that are directly affected by changes in how they are represented to the public.

Gender equity within school-based athletics is a cultural issue that should continue to be emphasized and improved. However, predicting what a target population wants is much less sensitive (and effective) as compared to making a genuine effort to ask them about their actual preferences. It can be concluded that U.S. high schools, colleges, and universities should conduct focus groups and surveys among their female athlete populations to gain insight into their opinions and preferences regarding how they would like to be depicted. Additionally, a comprehensive survey on GSAM usage within NCAA DI programs would be of great benefit considering that they have the highest degree of visibility within, and impact on, our cultural attitudes regarding gender equity and the images associated with female athletes.

\section{References}

Anderson, D.M. (2016). U.S. High School Girls Sports and Booster Clubs. Choregia, 12 (2), 61-76.

Armentrout, S.M., C. Kamphoff, \& J. Thomae, (2014). Photographic Images in Sports Illustrated for Kids: An Analysis of Sport Coverage and Gender Representation. Women in Sport \& Physical Activity Journal, 22 (1), 37-47.

College Consolidates Mascots for Male, Female Teams. (2010). College Athletics \& the Law, 7 (4), 1.

Eitzen, D.S., \& M.B. Zinn, (1990). The Sexist Naming of Collegiate Athletic Teams and Resistance to Change. Journal of Sport \& Social Issues, 17 (1), 34-41. 
Frazier, J.W., \& W.R. Caines, (2015). Gender Equality in Private College Athletics: Is Title IX Having an Impact? International Journal of Education Research, 10 (1), 125-134.

Franks, R. (1982). What's in a Nickname: Exploring the Jungle of College Athletic Mascots. Amarillo, TX: Ray Franks Publishing Ranch

Fuller, J.R., \& E.A. Manning, (1987). Violence and Sexism in College Mascots and Symbols: A Typology. Free Inquiry in Creative Sociology, 15 (1), 61-67.

Hardin, M., E. Whiteside, \& E. Ash, (2014). Ambivalence on the Front Lines? Attitudes toward Title IX and Women's Sports among Division I Sports Information Directors. International Review for the Sociology of Sport, 49 (1), 4265.

Harper, J. (2003, May 9). Marketing, PC Endanger UMass Mascot. Washington Times, p. D4.

Huffman, S., C.A. Tuggle, \& D. S. Rosengard, (2004). How Campus Media Cover Sports: Equity Issue, One Generation Later. Mass Communication \& Society, 7 (4), 475-489.

McClung, L.R., \& E. M. Blinde, (2002). Sensitivity to Gender Issues: Accounts of Women Intercollegiate Athletes. International Sports, 6 (1), 117-134.

Rickabaugh, T.E., \& E.W. Rickabaugh, (2015). Culturally Insensitive Athletic Mascots: Do Future Leaders in Sport Care? The Journal of SPORT, 4 (2), 1-11.

Sanderson, J., \& K. Gramlich, (2016). "You Go Girl”: Twitter and Conversations about Sport Culture and Gender. Sociology of Sport Journal, 33, 113-123.

Schools Offered Help Dropping Native Logos: Adidas says it Will Donate Design Resources to Institutions Looking to Change Indigenous Mascots, Names. (2015, November 6) Toronto Globe and Mail, p. S4.

Senne, J. (2016). Examination of Gender Equity and Female Sport Participation in Sport. Sport Journal, 1, 1-10.

Steinfeldt, J.A., R.A. Zakrajsek, K.J. Bodey, K.G. Middendorf, \& S.B. Martin, (2013). Role of Uniforms in the Body image of Female College Volleyball Players. Counseling Psychologist, 41 (5), 791-819. 